\title{
Granular Cell Tumour of the Tongue in a 8-Year-Old Boy: A Case Report
}

\author{
Lucio Lo Russo $^{1}$, Silvia Falaschini ${ }^{1}$, Raffaele Ivan Cincione ${ }^{2}$, Grazia Zino ${ }^{3}$, Paolo Bucci ${ }^{4}$ and \\ Lorenzo Lo Muzio*,1,5
}

\author{
${ }^{I}$ Department of Surgical Sciences, University of Foggia, Foggia, Italy \\ ${ }^{2}$ Department of Biomedical Sciences, University of Foggia, Italy \\ ${ }^{3}$ S. Carlo - IDI I.R.C.S.S. - Rome, Italy \\ ${ }^{4}$ Department of Odontostomatological and Maxillo-facial Science, School of Medicine and Surgery, "Federico II" \\ University, Naples, Italy \\ ${ }^{5}$ Centro di Riferimento Oncologico Regionale della Basilicata (CROB), Istituto di Ricovero e Cura a Carattere \\ Scientifico, Rionero in Vulture, Potenza, Italy
}

\begin{abstract}
Granular cell tumor is a relatively uncommon benign neoplasm that occurs in almost any part of the body, with the head and neck region involved in 45 to $65 \%$ of the cases. The peak of incidence is generally in the fourth to sixth decades of life, while it is very rarely encountered in children. Usually, it appears as a singular nodular mass covered by intact overlying mucosa. Its etiology and histogenesis is unclear; in addition, its nature is sometimes questioned due to the occurrence of malignancy in less than $2 \%$ of all lesions, and/or recurrence or metastasis to regional lymph nodes despite a benign histopathological appearance.

In the present paper, we describe a case with intraoral location occurred in a child, whose clinical and immunohistopathological features seem to confirm a benign course of tumor even in the childhood.
\end{abstract}

Keywords: Granular cell tumor, childhood, Abrikossoff tumor.

\section{INTRODUCTION}

Granular cell tumor (GCT) was first described by Abrikossoff in 1926 and postulated to be of myogenic origin [1]. Over time, GCT has been also termed myoblastoma, granular cell neurofibroma or granular cell schwannoma. Usually, it appears as a singular lesion, less than $3 \mathrm{~cm}$ in size; the surface is generally pink or occasionally yellowishwhite in colour. The nodular mass is hard, firm, sessile and covered by intact overlying mucosa [2]. It is benign in nature; however, malignancy rate is estimated to be less than $2 \%$ of all lesions, and cases have been reported where recurrence or metastasis to regional lymph nodes occurred, despite a benign histological appearance [3]. The aggressive form is associated with a high mitotic index and cellular pleomorphism [4].

We are herein reporting a case of intraoral GCT occurred in a child, thus being of particular interest since the tumour is very rarely reported in paediatric and/or adolescent population. Clinical and histological aspects have been discussed; in addition, the presence and the distribution pattern of markers such as S-100 protein, CD68 and CD57 have been analysed by immunohistochemistry in order to evaluate the neurogenic origin of the tumor.

*Address correspondence to this author at the University of Foggia, Faculty of Medicine, V.le Pinto, 1, 71100 Foggia, Italy; Tel: +390881588090; Fax: +390881588081; E-mail: 1lomuzio@tin.it

\section{CASE PRESENTATION}

A 8-year-old white child with a one-year history of a painless swelling under the tongue was referred to us. The swelling progressively increased in size causing slight discomfort especially during mastication. The patient had a dermoid cyst in the left eyebrow removed by surgery five years before, but was otherwise healthy, and haematological parameters were within normal limits.

Clinical oral examination revealed a single nodular mass, $1 \mathrm{~cm}$ in size, yellowish-white in colour located on the left margin under the tongue (Fig. 1). The lesion was tender and adherent to underlying structures. Excisional biopsy under local anaesthesia was performed in order to remove the lesion. The specimen was fixed in $10 \%$ buffered formalin and embedded in paraffin. $4 \mu$ histological sections from the paraffin-embedded block were stained using haematoxylineosin. Histologically, the lesion was composed of sheets and nests of plump round or polygonal cells containing abundant slightly eosinophilic granular cytoplasm with small, round, centrally located uniform pyknotic nuclei (Fig. 2). These findings were consistent with CGT. In general, mitoses are rare and necrosis is absent within these lesions. The growth pattern varies with the age of the lesion; while the cells tend to form large nests surrounded by thin fibrous septae in younger lesions, the pattern of older lesions is characterised by marked desmoplasia with few scattered small nests of granular cells embedded in a dense collagenous stroma [5]. 


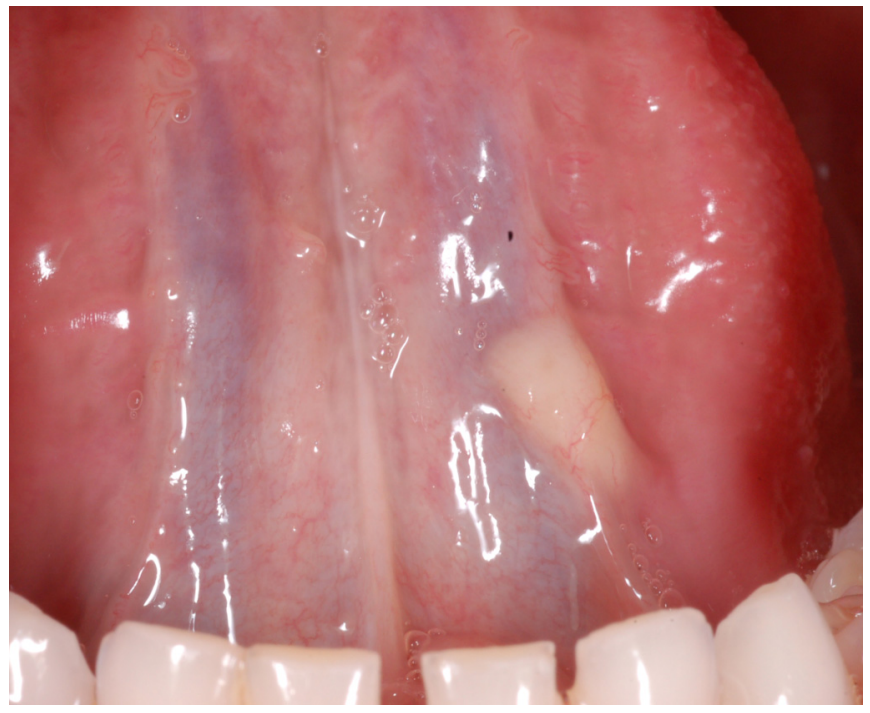

Fig. (1). Clinical aspect of the lesion.

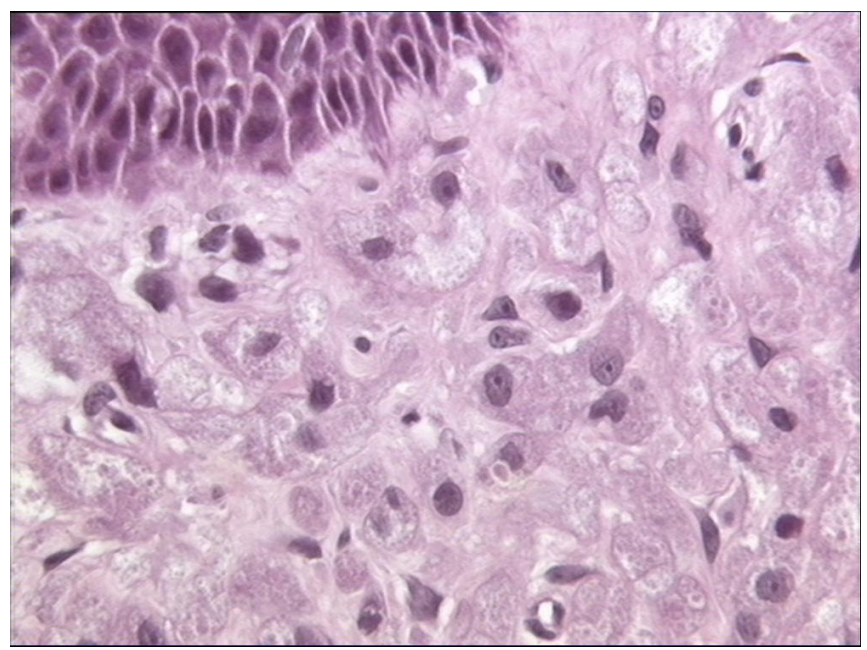

Fig. (2). Histological aspect of the lesion (Ematoxylin-Eosin 400X).

Immunohistochemical stain was performed with the avidin-biotin peroxidases complex. The granular cell tumors show immunoreactivity for S-100 protein (Fig. 3), vimentin, neuron-specific enolase (NSE), CD68 and CD57[6] [7]. We used the following monoclonal primary antibodies: antiCD68 (PG-M1, prediluited; DAKO, Carpinteria, CA, USA), anti-CD57 (QBEND-10, DAKO, Carpinteria, CA, USA) and S-100 protein (polyclonal, prediluited, Dako). Deparaffised and rehydrated sections were incubated for 30 minutes in $3 \%$ $\mathrm{H} 2 \mathrm{O} 2 /$ methanol to quench endogenous peroxidase activity and then rinsed for 20 minutes with phosphate-buffered saline (PBS). Non-specific protein binding was attenuated by incubation for 30 minutes with $5 \%$ horse serum in PBS. Specimens were incubated overnight with the monoclonal mouse antihuman CD57, CD68 and S-100 protein. The antibody was applied directly to the section and the slides incubated overnight $\left(48^{\circ} \mathrm{C}\right)$ in a humidified chamber. The sections were washed 3 times with PBS at room temperature. Immune complexes were subsequently treated with the secondary biotinylated antibody and then detected by streptavidin peroxidase, both incubated for 30 minutes at room temperature (Vectastain ABC kit, Vector Laboratories, Burlingame, Calif). After rinsing with 3 changes of PBS the immunoreactivity is visualised by development for 2 minutes with $0.1 \% \quad 3,3 \mathrm{~V}$-diaminobenzidine and $0.02 \%$ hydrogen peroxide (DAB substrate kit, Vector Laboratories). Sections were counterstained with Mayer's haematoxylin, mounted with permanent mounting medium, and examined by light microscopy. Semiquantative analysis of immunohistochemical staining was performed in 25 random fields using a conventional microscope with high potency of magnification (400X).

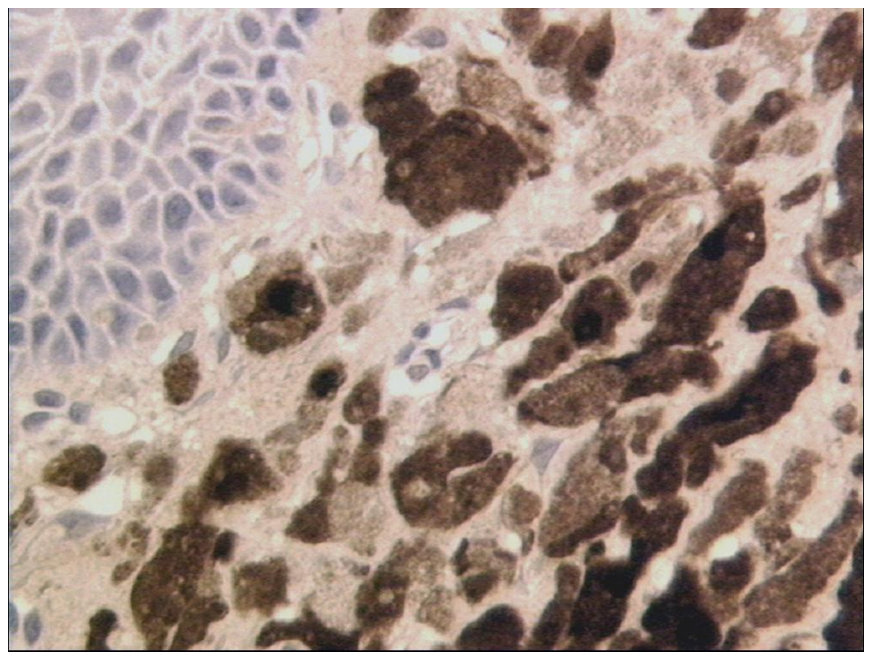

Fig. (3). Immunoreactivity of the lesion for S-100 protein.

The patient is periodically reviewed at six-months intervals to evaluate for recurrence and malignant transformation. The last follow-up, performed at 3 years, showed good healing without any evidence of disease.

\section{DISCUSSION}

GCT is a relatively uncommon benign neoplasm that occurs in almost any part of the body including skin, subcutaneous tissues of the chest, nervous system, gastrointestinal tract [8], urinary bladder, female reproductive tract and bronchus [9]. About 45 to $65 \%$ of the patients have the head and neck region involved, $70 \%$ of which presents intra oral lesions. The tongue, buccal mucosa, hard palate are the most frequent oro-facial localisation [10]. The tumour is rare in children: there are only few studies, besides the present case, that describe the occurrence in the childhood [11] [12] [13]; the peak of incidence is generally in the fourth to sixth decades of life. Some authors [14] observed a greater prevalence among women, while others [15] were not able to verify gender differences.

The etiology is unclear and there are several hypotheses concerning the histogenesis of GCT [16]. Myoblasts, Schwann cells, histiocytes, perineural fibroblasts, and undifferentiated mesenchymal cells have been postulated as the origin of the tumor [6]; on the other hand, theories for a non-neoplastic nature of the lesion resulting from trauma, a degenerative process or a storage disorder involving histiocytes have been also proposed [5]. Nonetheless, some studies support a peripheral nerve-related cells origin for the majority of these tumors based on the finding of cytoplasmic granules with numerous membrane-bound vacuoles containing myelin-like tubules and showing some relationships with pre-existent axons [6] [7] [17]. This neurogenic origin is supported by the immunohistochemical 
localisation of neuron specific enolase and S-100 protein markers in the tumor cells [18]. The differential diagnosis must be done with other benign connective and neural tumors, as fibromas, lipomas, pleomorphic adenoma of the minor salivary glands of the tongue, dermoid cyst and neuromas, neurofibromas. Clinical diagnosis of GCT is difficult because of the similarity in shape and colour with other epithelial lesions; therefore the histological examination including antibody anti S-100 protein will help in establishing the definitive diagnosis.

The majority of tumors has a benign clinical course; thus, the treatment of choice is the conservative surgical excision of the lesion [19], while the use of adjuvant radiotherapy is controversial. When surgical removal is correctly carried out, with margins of excision adequately positioned in clinical unaffected tissue, the prognosis is good, due to its slow growth and lack of aggressiveness. Since the GCT has a poorly defined margin it is suggested that the tumor should be excised along with portions of adjacent tissue. In $15 \%$ of cases, local relapse is possible due to incomplete excision of the tumor, whereas recurrence occurs in $1 \%$ to $3 \%$ of cases even in the case of complete removal [20]. Thus, a strict follow up is recommended in all cases to rule out relapses and to check for malignant transformation. Our case seems to confirm a benign course of tumor even in the childhood.

\section{REFERENCES}

[1] Abrikossoff A. Uber myome ausgehend von der quergesteiften willkurlchen musculator. Virchows Arch Pathol 1926;260: 215-23.

[2] Regezi JA, Sciubba JJ, Jordan RCK. Oral pathology. Clinical pathologic correlations. 5th ed. Saunders. 2007.

[3] Curtis BV. Calcaterra TC, Coulson WF. Multiple granular cell tumour: a case report and review of the literature. Head Neck 1997; 19:634-7.

[4] Fisher ER, Wechsler H. Granular cell myoblastoma: a misnomer. Electron microscopic and histochemical evidence concerning its schwann cell derivation and nature (granular cell schwannoma). Cancer 1962; 15:936-54.

[5] Morrison JG, Gray GF Jr, Dao AH, Adkins RB Jr. Granular cell tumours. Am Surg 1987; 53:156-60.

[6] Ordóñez NG, Mackay B. Granular cell tumour: a review of the pathology and histogenesis. Ultrastruct Pathol 1999; 23:207-22.

[7] Buley ID, Gatter KC, Kelly PM, Heryet A, Millard PR. Granular cell tumours revisited. An immunohistological and ultrastructural study. Histopathology 1988;12:263-74.

[8] Lack EE, Worsham GF, Callihan MD, et al. Granular cell tumour: a clinicopathologic study of 110 patients. J Surg Oncol 1980; 13:301-16

[9] Enzinger FM, Weiss SW. Soft tissue tumours. 2nd ed. St. Louis 1988; pp. 757-65..

[10] Gardner ES, Goldberg LH. Granular cell tumour treated with Mohs micrographic surgery: report of a case and review of the literature. Dermatol Surg 2001; 27:772-4.

[11] Brannon RB, Anand PM. Oral granular cell tumours: an analysis of 10 new pediatric and adolescent cases and a review of the literature. J Clin Pediatr Dent 2004; 29:69-74.

[12] Nagaraj PB, Ongole R, Bhujanga-Rao BR. Granular cell tumour of the tongue in a 6-year-old girl-A case report. Med Oral Pathol Oral Cir Bucal 2006; 11: 162-4.

[13] Senoo H, Iida S, Kishino M, et al. Solitary congenital granular cell lesion of the tongue. Oral Surg Oral Med Oral Pathol Oral Radiol Endod 2007; 104:45-8.

[14] Nishida M, Inoue M, Yanai A, Matsumoto T. Malignant granular cell tumour in maseter muscle: case report J Oral Maxillofac Surg 2000; 58: 345-8.

[15] Billeret Lebranchu V. Granular cell tumour: epidemiology of 263 cases. Arch Anat Cytol Pathol 1999; 47:26-30.

[16] Moseley I. Granular cell tumour of the orbit: radiological findings. Neuroradiology 1991; 33:399-402.

[17] Seo IS, Azzarelli B, Warner TF, Goheen MP, Senteney GE. Multiple visceral and cutaneous granular cell tumours. Ultrastructural and immunocytochemical evidence of Schwann cell origin. Cancer 1984; 53: 2104-10.

[18] Nakazato Y, Ishizeki J, Takahashi K, Yamaguchi $H$. Immunohistochemical localization of S-100 protein in granular cell myoblastoma. Cancer 1982; 49:1624-8.

[19] Poveda R. Granular cell tumour. Med Oral 2004; 9:362.

[20] Goodstein ML, Eisele DW, Hyams VJ, Kashima HK. Multiple synchronous granular cell tumours of the upper aerodigestive tract. Otolaryngol Head Neck Surg 1990; 103:664-8. 